\begin{abstract}
Iranica
Abstracta Iranica Revue bibliographique pour le domaine irano-aryen

Volume 34-35-36 | 2017

Comptes rendus des publications de 2011-2013
\end{abstract}

\title{
Kristin Kleber. Famine in Babylonia. A microhistorical approach to an agricultural crisis in 528-526 BC
}

\section{Astrid Nunn}

\section{(2) OpenEdition}

Journals

Édition électronique

URL : http://journals.openedition.org/abstractairanica/41590

DOI : 10.4000/abstractairanica.41590

ISSN : 1961-960X

Éditeur :

CNRS (UMR 7528 Mondes iraniens et indiens), Éditions de l'IFRI

Référence électronique

Astrid Nunn, « Kristin Kleber. Famine in Babylonia. A microhistorical approach to an agricultural crisis in 528-526 BC », Abstracta Iranica [En ligne], Volume 34-35-36 | 2017, document 43, mis en ligne le 15 juillet 2016, consulté le 28 septembre 2020. URL : http://journals.openedition.org/abstractairanica/ 41590 ; DOI : https://doi.org/10.4000/abstractairanica.41590

Ce document a été généré automatiquement le 28 septembre 2020.

Tous droits réservés 


\title{
Kristin Kleber. Famine in Babylonia. A microhistorical approach to an agricultural crisis in 528-526 BC
}

\author{
Astrid Nunn
}

\section{RÉFÉRENCE}

Kristin Kleber. « Famine in Babylonia. A microhistorical approach to an agricultural crisis in 528-526 BC ». ZA, 102, 2012, p. 219-244.

1 L'A. rassemble les documents et les lettres des archives de l'Eanna qui relatent les mauvaises récoltes et la véritable famine du début du règne de Cambyse ( $1^{\mathrm{e}} \mathrm{à} 4^{\mathrm{e}}$ année, 528 à 526 av. J.-C.). On ne peut aujourd'hui reconstruire la cause du manque d'orge. Une pénurie d'eau serait envisageable. Combler les lacunes avec un import semble avoir demandé une logistique qui dépassait les moyens de l'époque. L'A. nous informe sur l'impact socio-économique de cette famine, sur les tensions entre administrateurs et travailleurs du temple, qui même firent la grève.

\section{AUTEURS}

\section{ASTRID NUNN}

Université de Munich 